\title{
Legal support of the activities of the customs authorities as a factor of the sustainable development of the Russian economy
}

\author{
Nikolay Mikhailovich Kozhukhanov*, Bata Igorevich Ketsba, and Yuri Ivanovich Somov \\ State Public Educational Institution of Higher Education "Russian Customs Academy", \\ Komsomolsky Prospect, 4, 140015 Lyubertsy, Russia
}

\begin{abstract}
Poor quality and insufficient legal support for the activities of the customs authorities have a negative impact on the development of the Russian economy. The conducted evaluative historical and legal studies of the legal support of the activities of the customs authorities of the Russian Federation indicate the need for a detailed study of the regulations governing the activities of the customs. The study of the features of the current state of legal support for the activities of the customs authorities of the Russian Federation in the conditions of the functioning of the Eurasian Economic Union expands the empirical material that was collected in the course of the study, which makes it possible to apply the results obtained to study the influence of the supranational legal regulation on customs legal relations at the national level. The presented value judgments can be used in forecasting the development of the Russian economy. To establish the effectiveness of the legal support for the activities of the customs authorities and establish its impact on the sustainable development of the Russian economy, it is necessary to scientifically justify the methodological foundations that reveal the action of such a mechanism.
\end{abstract}

\section{Introduction}

Legal support for the activities of the customs authorities of the Russian Federation (hereinafter referred to as the customs authorities) is important in various aspects, both in a simplified inquiry [1] and in organizing customs control, both in promoting the development of foreign trade and in the work of the risk management system. Legal support covers a wide range of public relations related to customs activities regulated by the law.

According to the author's position, characterizing the customs activities, we affirm the following - “... customs activities are a dynamically developing sphere of society's life ... integration processes in which the Russian Federation actively participates directly affect the development of the customs activities, the organization of which is predominantly imperative ... the target setting of the subjects of customs activities serves not only as a criterion for their classification, but also as a logical basis for uniting the subjects of the customs legal relations into a single system" [2].

*Corresponding author: 1979nic@mail.ru 
The subjects of the customs activities are diverse, these are the executive authorities that regulate the customs business (in particular, the customs authorities), and various individuals and legal entities that own the goods, and persons carrying out their activities in the field of customs and other participants in customs legal relations. Some people control, manage this process, others are involved in it as the objects being managed. The customs authorities act as a key control and supervisory body regulating the issues of customs control, while directly implementing it.

High-quality legal regulation - legal support for the activities of the customs authorities, largely determines the effectiveness of their work and the achievement of their goals and objectives. The key tasks that the customs authorities solve in accordance with Article 351 of the Customs Code of the Eurasian Economic Union are as follows:

1) protection of the national security of the Member States, human life and health, flora and fauna, the environment;

2) creation of conditions for accelerating and simplifying the movement of goods across the customs border of the Union;

3) ensuring the execution of international treaties and acts in the field of customs regulation, other international treaties and acts that constitute the law of the Union, the legislation of the Member States on customs regulation, as well as the legislation of the Member States, control over the observance of which is entrusted to the customs authorities.

By protecting the national security (in particular, economic security), speeding up and simplifying the process of moving goods across the customs border, the customs authorities contribute to the development of the Russian economy. So, in different years, from 40 to $50 \%$ of the country's budget revenues come from the customs payments (according to information from the official website of the Federal Customs Service of Russia). And this is not all the contribution that the customs authorities make to the development of the economy of the Russian Federation. After all, contributing to the acceleration of the movement of goods, the turnover increases, and hence the income of producers of goods and services. The acceleration of the movement of goods, as a rule, occurs due to the introduction of advanced information technologies into the work of customs authorities (digitalization of customs). This requires the restructuring of many processes within the service, from the organization of activities to the methods enshrined in regulations, customs control, which are based on customs and administrative legislation. Thus, given that the activities of the customs authorities largely depend on their legal regulation, the legal support of the activities of customs authorities acts as a factor in the sustainable development of the Russian economy.

At the same time, if we look at the practice of resolving the issue of legal support for the activities of the customs authorities, there is a tendency to narrow the range of what the customs authorities understand by legal support of their activities. So, according to the information presented in the Annual Collection "The Customs Service of the Russian Federation", the Federal Customs Service of Russia (hereinafter - FCS of Russia), when reporting on the issue of legal support, usually shows the following information: the dynamics of claims and complaints filed against the actions of the customs officials; main categories of decisions, actions (inaction) of the customs authorities and their officials, appealed in court; the main categories of decisions, actions (inaction) of the customs authorities and their officials appealed in pre-trial procedure; the ratio of the number of court cases on claims against the customs authorities, considered not in favor of the customs authorities, to the total number of cases considered by the courts; etc. At the same time, it would be necessary to focus not only on the above details, but, first of all, to point out the problems of legal support for the activities of the customs authorities, which do not allow to more effectively solve the tasks facing the customs authorities. 
Insufficient legal support quality for the activities of the customs authorities contributes to the growth of offenses and crimes in this area, which is largely associated with the criminal migration of capital. Criminal capital migration has objective reasons, since it allows the persons who carry it out to evade taxes and other mandatory payments; reduce investment risks, protect themselves from inflation and the fall of the national currency; legalize income. Some of the acts related to the criminal migration of capital form the composition of acts entailing criminal liability, and others - civil or administrative one. However, all of them cause socially dangerous consequences for Russia, such as: deepening of the investment crisis; decrease in the effectiveness of economic policy; criminalization of the economy; influence on the exchange rate and the state of the foreign exchange market; influence on the formation of the revenue side of the budget; reduced ability of the state to service public debt; limiting the efficiency of transactions [3], etc. The turnover of corrupt money in the shadow sector of the economy, according to the World Bank, is estimated at 1 trillion dollars, a number of experts indicate that at least $1 / 3$ of the given amount falls on Russia [4]. Thus, the economic development of the state is seriously damaged.

Thus, all of the above allows us to trace the direct relationship between the legal support of the activities of the customs authorities and the sustainable development of the Russian economy.

\section{Methodological foundations of legal support for the activities of the customs authorities}

Speaking about the methodological foundations of legal support for the activities of the customs authorities, we will consider this issue in the context of "classification of legal support for the activities of customs authorities" and "systematization of entities that affect the legal support of the activities of the customs authorities."

The classification of legal support for the activities of customs authorities allows a systematic approach to the issue of understanding the internal processes and phenomena that are associated with the phenomenon under consideration. On the one hand, legal support as such is a process, a constantly functioning mechanism. However, on the other hand, legal support is a certain result, the final product that arises as a result of the implementation of a certain activity. Therefore, the criteria for the classification of legal support for the activities of the customs authorities, in our opinion, for the purposes of the study, are: a mechanistic criterion and a static criterion. The mechanistic criterion that allows to classify the legal support for the activities of the customs authorities is primarily related to the processes that are carried out in the legal support:

- legal support for the creation of regulations governing customs activities (activities of the customs authorities);

- legal support for the individualization of the rights and obligations of participants in customs legal relations;

- legal support for the realization of regulations governing customs activities (activities of the customs authorities). That is, within the framework of the mechanistic criterion, the legal support of the activities of customs authorities can be divided into the processes:

1) on the creation of normative legal acts regulating the customs activities;

2) allowing for the individualization of the rights and obligations of participants in customs legal relations;

3) related to the implementation of regulations governing customs activities.

The static criterion classifies the legal support for the activities of the customs authorities based on specific legal acts, which are objectively related to the stages of legal regulation. Based on the foregoing, in our opinion, within the framework of the static 
criterion, the legal support of the activities of the customs authorities can be grouped as follows:

A) regulations governing the customs activities;

B) legal acts of individualization of the rights and obligations of the participants in customs legal relations;

C) acts of enforcement related to the customs activities [4].

Speaking about the system of the entities providing legal support for the activities of the customs authorities in modern conditions, it should be said that the implementation of legal support for the activities of the customs authorities is personified, i.e. due to the actions of various actors. The study of the system of subjects providing legal support for the activities of the customs authorities in modern conditions is important and objective, it is necessary to form a holistic picture of the phenomenon under study.

Bodies of the legislative branch of the state power form the basis of the legal support for the activities of the customs authorities, creating federal constitutional and federal laws. At the highest level, these bodies are represented by two chambers of the Federal Assembly.

The bodies of the executive branch of state power issue by-laws, which detail and concretize the provisions of laws regulating the activities of customs authorities in modern conditions. By-laws of the Government of the Russian Federation are various kinds of decrees and orders, which, in turn, are supplemented by orders of various ministries and departments. The place of the President of Russia in the system of public authorities is controversial, without going into the details of this polemic, however, we note that his decrees have a direct impact on the legal support of the activities of the customs authorities. They have supreme legal force in relation to the acts of the Government, but they are also only by-laws. A special role in the legal support of the activities of the customs authorities lies with the FCS of Russia, which is currently subordinate to the Ministry of Finance of the Russian Federation, which carries out additional adjustments to the profile regulatory legal regulation of the customs activities and directly implements the prescriptions of the customs legislation of the Russian Federation. Participate in the legal support of the activities of the customs authorities and courts. Their capabilities in this direction are primarily related to the direct adoption of the decisions on the controversial issues that are related to the activities of the customs authorities, and they also issue verdicts on the offenses (hereinafter in the text in the broad sense of the word) attributed to their jurisdiction. The legal support of the activities of the customs authorities on the part of the courts should also include the decisions of the Plenums of the Supreme Court of the Russian Federation in relation to various categories of cases related to the offenses in the customs activities. All of these state authorities form hierarchical verticals of power, directly influencing the formation of legal support for the activities of the customs authorities, i.e. act as entities that provide legal support for the activities of the customs authorities in modern conditions.

The governing bodies of the Eurasian Economic Union (hereinafter referred to as the EEU) occupy a special place among the entities that provide legal support for the activities of the customs authorities in modern conditions. With the creation of EEU, of which the Russian Federation is a member state, a different from purely sovereign (within the state) regulation in relation to the customs activities arose, which directly affected the customs authorities. At the same time, EEU creates the acts that are international in nature. According to D.A. Postnova, many international legal acts allow for such directions and forms of international cooperation that are not provided for to the customs authorities by domestic legislation [5]. On the one hand, this expands the possibilities for the activities of the customs authorities, on the other, it creates collisions in the course of enforcement of customs legislation. 


\section{Retrospective analysis of legal support for the activities of the customs authorities}

Conducting a retrospective terminological analysis of the term "legal support of the activities of the customs authorities", we note that this term consists of two parts. Its generic element is "legal support", and its specific element is "the activities of the customs authorities". If the specific element does not cause much controversy, then, oddly enough, the specific element is rather controversial.

There are different views on the issue concerning "what is a legal support". Consider the positions on the problem under consideration. A number of legal scholars equate legal support and legislative support. Samoilova A.A. in her article "Legal support for the prevention of penitentiary offenses in pre-revolutionary Russia" says: "Summing up the period under consideration of the development of the penitentiary system within the framework of the normative regulation of the activities for the prevention of the penitentiary offenses, we can conclude that there was no special legislation directly regulating the issues of prevention of these crimes in the Russian Empire" [6]. Shokhina S.O. in her "Public-private partnership: problems of legal support" publication, adheres to the following position - "the article discusses the issues of legislative support of publicprivate partnership ..." [7]. Thus, these authors narrow the semantic content of legal support, to only the issues of normative regulation (within the framework of laws and bylaws). On the other hand, Fedotova Yu.G. has a wider view of the issue under consideration more broadly - "what is legal support". So, in the article "Elements of the mechanism of administrative and legal support of the national security of the Russian Federation" the author gives the following statement: "Administrative and legal support of national security is not only the activity of authorized state bodies to create the conditions for the implementation of state functions in the field of defense and security by legal means and methods, as well as on the legal regulation of such means and methods, but also the result of this activity, which is a set of social relations that have a special functional orientation and purpose and are expressed in the goals and objectives of the administrative and legal support of the defense and security of the Russian Federation" [8]. In our opinion, the last of the authors excessively expands the content of the concept of "administrative and legal support".

A.N. Arzamaskin in his publication "Definition of the concept of" legal support": formulation of the problem" having considered the problem of the definition of "legal support" argues that "... one can come to the conclusion about the significant breadth of the concept of "legal support" due to a systematic approach to understanding the process of implementation of legal norms ..., ... in the composition of the legal support it is necessary to include the legal impact, since its elements are an active component of the totality of the means used in the implementation of the right" [9].

Summarizing what has been said earlier, we consider it possible to assert that the legal support of the activities of the customs authorities is a set of the legal instruments that allow the mechanism of legal regulation of the activities of the customs authorities of the Russian Federation to become valid and actually functioning. Efficiency and reality of functioning, allow to achieve the set goals (tasks) facing the mechanism of legal regulation of the activities of the customs authorities [10].

\section{Conclusions}

The definition of the classification criteria that allows to distinguish various types of legal support for the activities of the customs authorities can be based on both traditional approaches used in the theory of law and individual ones, dictated by the objectives of the 
study. We have proposed the author's classification criteria for the legal support of the activities of the customs authorities, which are: mechanistic and statistical criteria. Based on these criteria, various types of legal support for the activities of the customs authorities are distinguished. The developed classification allows a comprehensive approach to the issue of legal support for the activities of the customs authorities. In turn, only comprehensive legal support for the activities of the customs can be considered a factor in the sustainable development of the Russian economy. After all, there is not enough a "good" law; a detailed, well-developed mechanism for its implementation is needed.

The system of subjects providing legal support for the activities of the customs authorities in modern conditions is diverse and complexly structured. It includes the government and government bodies of the Russian Federation, as well as EEU bodies (structures of the Eurasian Economic Commission)

As practice shows, at present, improving the legal support of the customs authorities is an important, but not a priority, necessity or priority in the development of the customs service. The FCS of Russia as a whole controls the situation in the law enforcement direction of its activities. At the same time, it cannot be denied that improving the legal framework could lead to an improvement in the situation, for example, in terms of minimizing the risks of committing offenses and crimes related to the customs business, which contributes to the sustainable development of the Russian economy.

\section{References}

1. M.A. Samelyuk, S.I. Girko, S.V. Kharchenko, S.A. Tsepinskiy, N.V. Rumyantsev, International journal of innovation, creativity and change, 7(12) (2019)

2. N.M. Kozhukhanov, Bulletin of the Russian Customs Academy, 2 (2014)

3. A. S. Evstigneev, I.N. Slyunyaev, New Criminal Situation: Assessment and Response (2009)

4. S.R. Gosteva, V. F. Rashkin, Corruption in Russia: Monograph (2010)

5. N.M. Kozhukhanov, Collection of materials of the VIII interdepartmental scientific and practical conference of the law faculty of the Russian Customs Academy, dedicated to the 25th anniversary of the Constitution of the Russian Federation (2019)

6. D.A. Postnova, Development of the theoretical, legal and organizational foundations of international cooperation of the customs authorities of the Russian Federation in the detection and investigation of the customs crimes (2006)

7. A.A. Samoilova, Penal system: law, economics, management, 5 (2018)

8. S.O. Shokhin, Lawyer, 2 (2018)

9. Yu.G. Fedotova, Modern Law, 7-8 (2018)

10. A.N. Arzamaskin "Definition of the concept of "legal support": problem statement having considered the problem of the definition of "legal support", https://cyberleninka.ru/

11. N.M. Kozhukhanov, Bulletin of the Russian Customs Academy, 2 (2019) 